\title{
Energy Collection Efficiency of Solar Collector with Nano Carbon- $\mathrm{Cr}_{2} \mathrm{O}_{3}$ Coated Absorber
}

\author{
S. Selvakumar ${ }^{1 *}$, T.R. Rajasekaran ${ }^{1}$, V.Sabarinathan ${ }^{2}$, R.V. Jeba Rajasekhar ${ }^{3}$ \\ 1* Department of Renewable Energy Science, Manonmaniam Sundaranar University,Tirunelveli, Tamilnadu, India, 627012 \\ ${ }^{2}$ Department of Physics, Manonmaniam Sundaranar University,Tirunelveli, Tamilnadu, India, 627012 \\ ${ }^{3}$ P.G \& Research, Department of Physics, Government Arts College, Melur, Tamilnadu, India, 625106 \\ *Corresponding Author: kumartvl88@gmail.com , Tel.: +91-9042474329
}

Available online at: www.isroset.org

Received: 29/Oct/2018, Accepted: 27/Nov/2018, Online: 31/Dec/2018

\begin{abstract}
The experimentation on solar absorber and collector is mandatory so as to have their effective utilization in energy intensive sectors. In this connection, experimentation in connection with the characterization of nano carbon $\operatorname{and~} \mathrm{Cr}_{2} \mathrm{O}_{3}(60: 40)$ coated solar absorber was carried out. In addition, experimentation in connection with the estimation of efficiency of solar collector and device was carried out as per BIS specifications. The outcomes of experimentation on solar absorber revealed that the crystallite sizes in the carbon and $\mathrm{Cr}_{2} \mathrm{O}_{3}(60: 40)$ coating on absorber were in nano ranges. The outcomes of experimentation on solar collector and device revealed that the instantaneous thermal performances of solar flat plate collector ranged between $66.9 \%$ and $68.6 \%$ and energy collection efficiency of solar heating device was $51.4 \%$. As the thermal performances of the solar collector and device could distinctively depend on the optical characteristics of the absorbers, it could be concluded that nano carbon and $\mathrm{Cr}_{2} \mathrm{O}_{3}(60: 40)$ coated solar absorbers would be effectively used in solar collectors and heating devices.
\end{abstract}

Keywords:Nanostructured absorber, Solar collectors and devices, Improved thermal performances

\section{INTRODUCTION}

Solar heating device is one of the technically matured solar thermal devices. It has two major components such as flat plate collector and storage tank [2]. It has been reported that the thermal performance of solar device can be improved by incorporating metal absorbers with relatively higher thermal conductivity. It has also been reported that the thermal performance of solar device can be further improved by incorporating metal absorbers with nanostructured coating on them [3]. In this connection, the present research work was carried out (i) to assess the structural characteristics of the nano carbon and $\mathrm{Cr}_{2} \mathrm{O}_{3}$ (60:40) coated absorber, (ii) to estimate the instantaneous thermal performance of flat plate collector with nano carbon and $\mathrm{Cr}_{2} \mathrm{O}_{3}$ (60:40) coated absorber and (iii) to evaluate the energy collection efficiency of solar heating device. The standard materials, BIS test methods and calibrated test instruments were used for materializing all these objectives. The research outcomes have been recorded in the present research paper for the benefits of researchers, manufacturers and end users of solar thermal devices. As far as the organization of the research paper is concerned, the first section provides the introduction and the second section provides the materials and methods of the present research work. The third and fourth sections provide the results, discussion and conclusion of the present research work.

\section{MATERIALS AND METHODS}

The test samples of the present research included (i) nano carbon and $\mathrm{Cr}_{2} \mathrm{O}_{3}$ (60:40) coated absorber (ii) solar flat plate collector with nano carbon and $\mathrm{Cr}_{2} \mathrm{O}_{3}$ (60:40) coated absorber and (iii) solar heating device. While the nano carbon and $\mathrm{Cr}_{2} \mathrm{O}_{3}(60: 40)$ coated absorber was characterized through XRD, the flat plate collector was tested as per BIS specifications and the solar heating device was tested as per energy collection efficiency test procedures [1]. It is to be noted that the stead state conditions and test conditions were strictly maintained for testing the flat plate collector and solar heating device. It is also to be noted that the flat plate collector and solar heating device were tested in outdoor conditions and the influencing parameters were recorded. The thermal performance of flat plate collector and solar heating device was individually calculated with the formulae such as

$$
\begin{aligned}
& \eta=m_{f} C_{p}\left(T_{o}-T_{i}\right) / A_{g} G \\
& \eta=m_{f} C_{p}\left(T_{f s}-T_{i s}\right) / A_{g} G_{I}
\end{aligned}
$$

Where $\eta=$ efficiency $(\%), \mathrm{m}_{\mathrm{f}}=$ mass flow rate of working fluid $(\mathrm{Kg} / \mathrm{s}), \mathrm{Cp}=$ specific heat capacity $\left(\mathrm{J} / \mathrm{kg}^{\circ} \mathrm{C}\right), \mathrm{T}_{\mathrm{o}}=$ outlet temperature of the working fluid $\left({ }^{\circ} \mathrm{C}\right), \mathrm{T}_{\mathrm{i}}=$ inlet temperature of the working fluid $\left({ }^{\circ} \mathrm{C}\right), \mathrm{T}_{\mathrm{fs}}=$ final temperature of the 
working fluid in storage tank $\left({ }^{\circ} \mathrm{C}\right), \mathrm{T}_{\text {is }}=$ initial temperature of the working fluid in storage tank $\left({ }^{\circ} \mathrm{C}\right), \mathrm{A}_{\mathrm{g}}=$ gross area of collector $\left(\mathrm{m}^{2}\right), \mathrm{G}=$ incident solar radiation $\left(\mathrm{W} / \mathrm{m}^{2}\right)$ and $\mathrm{G}_{\mathrm{I}}=$ integrated solar radiation $\left(\mathrm{KJ} / \mathrm{m}^{2} \mathrm{~s}\right.$ per day) [1].

\section{RESULT AND DISCUSSION}

The present research work was devoted not only to assess the structural characteristics of solar absorber but also to evaluate the thermal performances of solar flat plate collector and heating device. While the generated diffractogram has been presented in Figure 1, the recorded parameters during the performance tests have been presented in Table 1 and Table 2 respectively.

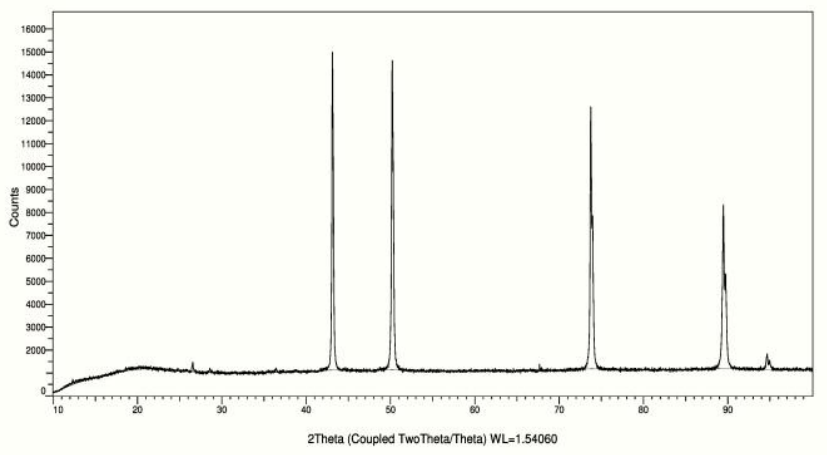

Figure 1. Diffractogram of the nano carbon and $\mathrm{Cr}_{2} \mathrm{O}_{3}(60: 40)$ coated absorber.

Table 1 : Recorded parameters and thermal performance of solar flat plate collector

\begin{tabular}{|c|c|c|c|c|c|c|}
\hline \multirow{2}{*}{$\begin{array}{c}\text { Time } \\
(\mathrm{Hr})\end{array}$} & $\begin{array}{c}\text { Solar } \\
\text { radiation } \\
\left(\mathrm{W} / \mathrm{m}^{2}\right)\end{array}$ & $\begin{array}{c}\text { Ambient } \\
\text { temperature } \\
\left({ }^{\circ} \mathrm{C}\right)\end{array}$ & \multirow{2}{*}{$\begin{array}{c}\text { Wind } \\
\text { speed }\end{array}$} & \multicolumn{2}{|c|}{$\begin{array}{c}\text { Temperature } \\
\text { of fluid }\left({ }^{\circ} \mathrm{C}\right)\end{array}$} & Instantaneous \\
\cline { 5 - 6 } & & Inlet & Outlet & $(\%)$ \\
\hline $11: 00$ & 740.2 & 30.5 & 0.5 & 30.0 & 36.6 & 68.6 \\
\hline $11: 30$ & 762.9 & 30.8 & 0.6 & 30.0 & 36.7 & 67.8 \\
\hline $12: 30$ & 787.0 & 31.0 & 0.2 & 30.0 & 36.9 & 67.6 \\
\hline $13: 00$ & 822.0 & 31.4 & 0.4 & 30.0 & 37.0 & 66.9 \\
\hline
\end{tabular}

Table 2 : Recorded parameters and thermal performance of solar heating device

\begin{tabular}{|c|c|c|c|c|}
\hline $\begin{array}{c}\text { Time } \\
(\mathrm{s})\end{array}$ & $\begin{array}{c}\text { Outlet } \\
\text { temperature } \\
\left({ }^{\circ} \mathrm{C}\right)\end{array}$ & $\begin{array}{c}\text { Time } \\
(\mathrm{s})\end{array}$ & $\begin{array}{c}\text { Outlet } \\
\text { temperature }\left({ }^{\circ} \mathrm{C}\right)\end{array}$ & $\begin{array}{c}\text { Energy } \\
\text { collection } \\
\text { efficiency }(\%)\end{array}$ \\
\hline 120 & 70.8 & 840 & 75.8 & \multirow{2}{*}{5} \\
\cline { 1 - 3 } 5 & 71.4 & 76.2 & \\
\hline 360 & 72.6 & 1080 & 76.6 & \\
\cline { 1 - 4 } 480 & 73.5 & 1200 & 76.8 & \\
\hline 600 & 74.9 & 1320 & 77.0 & \\
\hline 720 & 75.4 & 1440 & 77.2 & \\
\hline
\end{tabular}

In the present research, the copper substrates were used. Their sizes were fixed as per BIS specifications. The nano carbon and $\mathrm{Cr}_{2} \mathrm{O}_{3}$ (60:40) coating was effected on copper substrates and the nano structured absorbers were prepared. Subsequently, the prepared absorbers were characterized through XRD. The crystallite sizes of the constituents of the coating on solar absorbers were calculated from the generated diffractogram and their magnitudes were found to be in nano ranges. The thermal durability test on the developed solar absorbers was conducted by adopting standard procedure and it was found to be acceptable [5].

In the present research, the temperature enhancements of working fluid were found to vary from 6.6 to $7.0^{\circ} \mathrm{C}$ for the minimum inlet temperature of the working fluid. The instantaneous thermal performances of solar flat plate collector were found to range between $66.9 \%$ and $68.6 \%$ with the same minimum inlet temperature of the working fluid. At the same time, the energy collection efficiency of solar heating device was found to be $51.4 \%$. While comparing the thermal enhancements of working fluid, instantaneous thermal performances and energy collection efficiency of the present solar device with those values of the conventional solar devices, it was noted that the thermal profile of working fluid in the present solar collector was better than that of the conventional collector. It was also noted that the performance profile of the present collector was better than that of the conventional collector. The observation on generated database revealed that energy collection efficiency profile of the present solar heating device was better than that of the conventional solar heating device [4]. The improved thermal enhancements of working fluid, thermal performances of solar collector and energy collection efficiency of solar heating device could have been caused due to the usage of nano textured glass cover, nano carbon and $\mathrm{Cr}_{2} \mathrm{O}_{3}(60: 40)$ coated solar absorber and novel wool insulation. They could also have been caused due to the improved transmittance of radiation, improved absorptance of radiation and reduced heat losses to the atmospheric environment as a result of the usage of nano textured, nano structured and novel components in solar heating device [5].

\section{CONCLUSIONS}

As the thermal performances of the solar collector and device could distinctively depend on the optical characteristics of the absorbers, it could be concluded that nano carbon and $\mathrm{Cr}_{2} \mathrm{O}_{3}$ (60:40) coated solar absorbers would be effectively used in solar collectors and heating devices.

\section{REFERENCES}

[1] BIS, 2005, IS 12933 (Part 1, 2, 3 \& 5: 2003 together with amendment No.1 of June 2005), Bureau of Indian Standards, India.

[2] J.A. Duffie, Beckman, W.A., Solar thermal engineering processes, A Wiley Interscience publication, New York, U.S.A. 1980.

[3] S.A. Kalogirou, "Solar Thermal Collectors and Applications Progress in Energy and Combustion Science", New York : Elsevier Science Publishing Company, Vol. 30, pp.231-295, 2004.

[4] K.Uma Maheswari, R.V.Jeba Rajasekhar, "Experimental estimation of the thermal performances of copper, aluminium and mild steel absorber integrated solar collectors", International Journal of Applied Research, Vol.2, Issue.11, pp.459-461, 2016

[5] T.Vasantha Malliga, R.V.Jeba Rajasekhar, "Preparation and characterisation of nanographite - $\mathrm{CuO}$ based absorber and performance evaluation of solar air heating collector", Journal of Thermal Analysis and Calorimetry, Springer Publications, Vol. 129, Issue 1, pp. 233-240, 2017. 